\title{
Frequently Used Terms
}

I use many transliterated Greek words in this book, translating the term when it first is used but not thereafter. For convenience, here are definitions of the most important terms. Plurals follow in parentheses.

agalma (agalmata) anything that delights a god, including a statue of the god or a tree or animal sacred to the god

aition (aitia) a myth explaining the origin of something alastōr (alastores) and elasteros (elasteroi) a vengeful ghost or an agent who works on the ghost's behalf

aōros, aōrē (aōroi, aōrai) a man or woman who dies too young ataphos (ataphoi) a dead person whose body has not received funeral rites

biaiothanatos (biaiothanatoi) a person who died violently choe (choai) a libation poured out to the dead eidōlon (eidōla) a ghost (literally "image") epōidèlepaoidè (epōidailepaoidai) a chanted or sung spell erinys (erinyes) a deity who works to avenge the dead, among other things 
gellō (gelloudes) a female ghost who attacks women and children (no plural of this word exists in ancient Greek; I had to adopt the plural form used in some Byzantine Greek sources)

genos (genē) kin (often with political implications)

goès (goètes) and goèteia an expert in dealing with disembodied souls and the art that he practices; hence, also "goetic" goös (gooi) a highly emotional funeral lament katharos (katharoi) and katharsis an adjective meaning "pure" and noun meaning "purification"

katabasis (katabaseis) a journey to the Underworld katadesmos (katadesmoi) a curse tablet $k \bar{e} r$ (kères) a supernatural agent who brings death or other misfortune kleos glory, renown

kourotrophos (kourotrophoi) one who nurtures children lamia (lamiai) a female ghost who attacks women and children lex sacra (leges sacrae) LATIN: law concerning religious practices lithica a work describing magical stones and their properties maschalismos the ritualized act of severing a corpse's extremities miaros (miaroi) and miasma (miasmata) an adjective meaning polluted and noun meaning pollution mormō (mormones) a female ghost who attacks women and children mormolukeion/mormolukè (mormolukeia/mormolukai) a female ghost who attacks women and children nekuia (nekuiai) an encounter between living and dead individuals, usually initiated through ritual nekuomanteion (nekuomanteia) an oracle in which the dead prophesy oikos (oikoi) a household or family palamnaios (palamnaioi) either a murderer or a spirit who avenges murder parthenos (parthenoi) a woman who has never been married pharmakon (pharmaka) and pharmakeutrides magical material, especially drugs, and the female specialists who gather and use them 
phasma (phasmata) and phantasma (phantasmata) ghosts progonoi progenitors prostropaios (prostropaioi) either a person (or god) who should be averted or a person (or god) or functions as an averter psychagōgos (psychagōgoi) and psychagōgia one who invokes souls and the art by which he does so

psychē (psychai) soul psychopompos (psychopompoi) a leader of souls strix (striges) a female ghost who attacks women and children teletē (teletai) rites, especially those associated with mysteries theos (theoi) a god, either male or female; but cf. thea (theai), goddess

theoxenia a meal to which a god is invited thrēnos (thrēnoi) a formal funeral lament, often professionally composed

xenos (xenoi) and xenia a guest with whom one has a formal friendship and the friendship itself 
This page intentionally left blank 